\title{
Implementation of Law on Village and Democratization Effort in the Villages
}

\author{
Wahidah R. Bulan, UIN Jakarta
}

\begin{abstract}
The implementation of Law of The Republic of Indonesia Number 62014 is aimed to strengthen and to develop the democratic atmosphere in the villages as well as to make a more dynamic and progressive village. One of the ways to do that is by reforming the functions of Village Consultative Board (BadanPermusyawaratanDesa or BPD). Another way is by implementing village deliberation as a more realistic and significant place for political involvement of villagers. Lastly, by creating a more democratic elections for village leader. The purpose of this study is to give details description of democratization practice in the village after the implementation of the village law. The study was taken place in four villages, two regencies in Central Java (Kebumen and Bantul) which was conducted from February to March 2016. This study was not only to assess the structural change aspects but also to elaborate social processes that took place in the process of democratization in the village after the implementation of Law No. 6 2014. The findings indicated that there are structural changes which tend to be without (minimal) excesses, but not on cultural aspects. However, the social process is still very dynamic as the implementation time of the new village law was quite short (two years), it still allowed the changes to occur in the future
\end{abstract}

Keywords - Indonesia, democracy, Law, Kebumen, Bantul

\section{INTRODUCTION}

Various efforts to promote and prosper the village have been done by many parties, and it came to the point of the enactment of Law No. 062014 about Village which considered as the most progressive policy throughout the history of the village struggle. One of progressive policy is related to village authorities. The village now has some authorities (article 18); authority in the field of village governance, village development, village community development, community empowerment based on community initiatives, and village rights and customs.

Authority is often regarded as an important element in the effort to encourage changes in the village. The underdeveloped village is often regarded as a result of the lack of village authority. Thus the effective way to develop village is starting to encourage the strengthening of village authority.

However, even though the authority is an important factor, various reform practices show that authority alone is not enough since official power as a potential power can only become actual when it meets with some other factors (Bulan, 2013). Other factors are included the ability to form initiatives or ideas of reform. As stated by Giddens (1984) it is a capability to make different. With some authorities, the village/region head is possible to take some innovation in resolving the issue. Besides, with authoritative powers, the initiative of the region or village head will make it able to develop expected changes.

In addition to reform initiatives (innovation), the courage is another factor (Bulan, 2013). The importance of courage to implement the ideas of change sometimes has to deal with many obstacles (such as structural obstacles; regulation availability, the readiness of bureaucratic institutions, as well as the availability of budget). The ability of actors to build relationships with multi-actors (state actors and non-state actors) is the other factors that cannot be underestimated (Bulan, 2013).In the book titled Bound to Lead: The Changing Nature of American Power (1990), Joseph Nee mentioned the whole thing (the ability to generate reform ideas, courage, relationship building skills, etc.) is as a soft power which is equally necessary to maximize hard power.

The study was conducted to identify the practice of the village (especially good practice in the village) after the enactment of the Village Law in three strategic issues, i.e. village governance, village finance, and BUMDes (Village owned enterprise); and the factors that influence it (push factor and pull factor). For this paper, the exposed results are only related to local governance, and more specifically related to democratization in the village that became the subdiscussion of the issue of local governance.

\section{RESEARCH METHOD}

This research was conducted by using the qualitative method with case study approach since the research explores more the research questions related to how or why that is how the problems complexity in the implementation of Law No. 6 The year 2014 and how the implementation process can produce useful practices.

For the place settings, this study was conducted in 7 villages located in three District from three provinces. The focus of the study was divided into three villages as the main locus (one village in each District) and four villages as a companion locus. The main focus (village) is determined based on the consideration of the achievement on the research objectives, which is to obtain a comprehensive, detail, and actual overview of the village's practices, as well as the availability of specified information in the village on three strategic issues. 
Furthermore, the selected villages are the best villages in the competition (Panggungharjo Village, Sewon Sub-district, Bantul District, New Brumbung Village, Dayun Sub-district, Siak Village and Pejengkolan Village, Kebumen District) or because of the well-known village practices (Petanahan village, Kebumen district).

\section{NORMATIVE REVIEW OF ACTIVE ACTIVITY AND SOCIAL PARTICIPATION}

In the effort to encourage the democratization process in the village, the sub-issue of this study is active citizenship. Referring to Etzioni (1968: 4), in the discussion of active societies, to be active can be translated to be in charge while to be passive on the contrary is to be under control. Thus active citizenship is intended as a description of citizens with a sense of responsibility, in this case, the responsibility of citizens is to conduct or encourage changes (in the context of this study, village changes). This understanding is relevant to Etzioni's claim that to be active is connected with one's ability to change himself or to be a creator.

Related to that, according to Michael Mann, who developed the theory of citizenship, he identified two important variables of citizenship, one of which is related to the passive or active citizenship nature that depends on whether the citizenship developed from above (through the state) or below (through the community). Thus citizenship heavily depends on the emergence and development, which whether grow and develop on the initiation of society itself (bottom up) or of full government by state.

Active citizenship, as expressed by Putnam (2000), cannot be separated from the social capital because active citizenship has a strong correlation with civic engagement that has an important role in building social capital. Both reciprocities contribute to make (and expand) a social networking based on the share value as its foundation, which in the next stage, it increases social trust and promotes cooperation and on the other, it reduces anti-social behavior. In that context, active citizenship contributes not only to social life but also to the economic life of society.

Also, active citizenship is also often associated with participation, so that active citizens can be translated as active participants. This is as expressed in the study of active citizenship for democracy coordinated by the European Commission of Centre for Research and Education and Lifelong Learning (CRELL) that active citizens are defined as people participation in political life, characterized by mutual respect and non-violence and under the rights human and human democracy (Hoskins, 2006). Furthermore, it is stated that active citizenship can be understood as participation in a very broad sense.

Hence, what is participation? According to Nasdian (2006), participation is defined as an active process in which citizens take the initiative to act, guided by their way of thinking, and by using the medium and processes (institutions and mechanisms) in which they can effectively control. Based on its type, participation can be distinguished into social participation, political participation, and development participation. In this paper, I only show one type of participation, namely political participation that define as associated with involvement in political activities, from the most primal such as participating in election activities (in this study the election of village head or known asPilkades), attending political meetings such as campaigns or rallies, becoming political party boards, promoting candidates for election, (Rush and Althoff).

\section{FINDINGS AND STUDY DISCUSSION}

Political Participation of Villagers: Democratizing Villages or Urging Democratization

The political participation of citizens which is giving equal opportunity to citizens to be able to be chosen fairly and transparently as mentioned in article 68 verse 1 evolves in a more positive direction. For example, there is sufficient space for women to be elected as village heads (the village heads of Petanahan and Pejengkolan are women). There is also the orientation to choose candidates who represent the change (no practice of KKN, for example), giving space to newcomers who have never been active in village activities to be elected as village head and defeat the incumbent (for example in Panggungharjo, Pejengkolan, and Petanahan Village). This also causes the village head now from a young people or not from those who are hereditary as village head or village apparatus.

The citizen enthusiasm in following the election also shows an exhilarating phenomenon. In the voter data collection activities that are now managed better, for example, the committee coming to the houses and even give the opportunity to the nomads to participate in the election. There is also a new phenomenon of citizens register themselves independently as voters, which seems to be the impact of the upper-level election (District/city and province). In the implementation of Pilkades activities, there is a tendency to follow the mechanism of Pilkada implementation. Although on the one hand this is a positive development of political participation of citizens, on the other hand it is feared to eliminate the basic dynamics of village politics, namely the relationship of village head with citizens that is now increasingly on political oriented relations and eliminating relations of social relationships between citizens and figures that have been exist. The practice of village democracy was not only to copy-paste the practice at the level above (Pilkada at the district, provincial level, especially at the central government level), because the typical democratic practices in the village should be originally preserved. For example, a relationship that is more oriented on social motives and not political motives such as volunteerism, cooperation, trust, and obedience. This is different from the political relations in the democratization process which is more oriented towards three things as defined by Dahl (1971) namely competition, participation, and freedom.

Though they are not entirely negative, they also hold negative sides and are not fully compatible with the village culture. Another aspect that also needs to be noticed is how to maintain relationships that are more oriented to groups' interests and not individual interests. As Peter Bachrach (1980: 24-98) pointed out, the supreme goal of democracy is a system of government that maximizes the development of the individual in which freedom is guaranteed. The village life with group orientation and also has relatively unspecified aspects of freedom needs to be carefully considered, so that the democratization process that wants to develop should not make the village lose its village character. Related to that, our 
main problem is not merely democratizing the village, but also how to push the democracy practice using village character.

\section{CONCLUSION}

Although it has been given wide authority to carry out its affairs through the Village Law, in practice, the village still tends to depend on the district government. In the village democracy implementation, citizen's articulation space is still not functioned optimally. BPD, as a representation of citizens, has not played an optimal role, and there is no effort to strengthen those roles, either from BPD itself or by citizens. The village authority to form Pardes is still not fully utilized. Not many local regulations are issued, other than the main rules such as APBDes. With full authority, there should be more and more rules on issued because of the consequences of many matters governed by the village itself. The mindset of the village head seems to have shown positive things, which the village head has begun to open up the democratic space, but it takes the courage to run it without fears of intervention from the district government.

The low quality of democracy affects the performance of the village government. Government performance is understood only as a physical development performance. The voices of the citizens towards the needs of development other than physical construction are still less accommodated. In the case of Panggungharjo, the undertaken development was more likely due to the will and initiative of the village head. Although it still referred to the citizen's wishes which delivered in Muses, the portion is relatively small. In Panggungharjo village, the democracy is realized through the work performance of Penedes. The good village government performance is expected to gain citizen trust, from there citizens' awareness of village democracy will grow.

As a unit of law society which has the authority to regulate and manage the government affairs and the interests of its people, in other words as the smallest unit of the village that face the citizen's life, the existence of society is a capital in the implementation of village development. The efforts to develop an active citizen in the village to progressive direction still have to go a long way. Although through the Village law the participation spaces have been wide opened so that the villagers can further strengthen their roles, the implementation is not easy. It takes some supportive interventions so that the policy spirit can reveal the expected result.

The main problem remains at the level of policy socialization. Many village heads, and villagers do not know (or even understand) the new spirit that will be endorsed in the law. This causes the substantive aspects of the law related to the development of active citizen in the village is failed to be understood by the village head and village apparatus or even to the village community. Good practice on the issue of the active citizen can occur because of the central role of the village head as the main actor of change. The practice can emerge and evolve due to a mixture of factors such as the village head's strong commitment to change (and the desire to advance the village), the readiness of village heads and village apparatus to receive and develop new values in village governance (transparency, IT, professionalism, accountability, etc.), the role of the village head actor as the central leader in the village, the ability of the village head to develop a good team work within the village administration, and equally important, the approach that adheres to the local values. In this way, the originality of local values can be maintained, although the changes towards village improvement can also be realized

\section{REFERENCES}

1. Adams, Julia. 2005. "The Rule of the Father: Patriarchy and Patrimonialism in Early Modern Europe" on "Max Weber's Economy and Society: A Critical Companion" by Charles Camic, Philip S. Gorski, dan David M. Trubek (editor). Stanford, California: Stanford University Press.

2. Antlöv, Hans andSutoroEko. 2012. "Village and SubDistrict Functions in Decentralized Indonesia." Paper to DSF's Closing Workshop.

3. Antlöv, Hans. 2002. "Negara dalamDesa: PatronaseKepemimpinanLokal", translation version byPujoSemedi. Yogyakarta: LAPPERA.

4. Blau, Peter M., \& Meyer, Marshall W. (2000). BirokrasidalamMasyarakat Modern (SlametRijanto, Translator). Jakarta: PrestasiPustakaraya.

5. Bulan, Wahidah R. 2013. ReformasiLokal di Kota Solo pada Era Jokowi (Tahun 2005-2012): TindakanAgenMempengaruhiStrukturdanRelasi

Multi AktorpadaKasusPenataan PKL danPemukimanBantaranBengawan Solo. Unpublished Dissertation.

6. Creswell, John. 2009. "Research Design: Qualitative, Quantitative, and Mixed Methods Approach" (3rd ed.). Thousand Oaks California: Sage Publications.

7. DirektoratPemerintahanDesadanKelurahanDirektorat JenderalPemberdayaanMasyarakatdanDesaDepartem enDalamNegeri. 2007. "NaskahAkademikRancanganUndangundangtentangDesa". Jakarta.

8. Etzioni, Amitai. 1968. The Active Society: A theory of Societal and Political Processes. The United Stated of America: The Free Press, A Division of The Macmillan Company.

9. Giddens, Anthony. 1995. The constitution of society: The outline of the theory of structuration. UK: Polity Press Cambridge.

10. Giddens, Anthony. 2003. The constitution of society: TeoriStrukturasiuntukAnalisisSosial (AdiLokaSujono, Translator). Pasuruan: Pedati.

11. Ife, JimandTesoriero, Frank. 2008. AlternatifPengembanganMasyarakat di Era Globalisasi: Community Development ( $3^{\text {rd }}$ Ed.) (SastrawanManulang, dkk; Translator). Yogyakarta: PustakaPelajar.

12. Jonathan H., Turner. 1990. The structure of sociological theory, California: Wadsworth Publishing Company.

13. Lamsal, Mukunda. 2012. "The Structuration Approach of Anthony Giddens" on Himalayan Journal of Sociology \& Anthropology-Vol. V.

14. Nye JR., Joseph. S. 1990. Bound to Lead: The Changing Nature of American Power. United States of America: Basic Books, a Member of Perseus Books, L.L.C. 
15. Nye JR., Joseph. S. 2004. Soft power: the means to success in world politics. New York, United State of America: Public Affairs.

16. Ritzer, George. dan Goodman, Douglas J. 2003. Modern sociology theory ( $6^{\text {th }}$ edition) (Alimandan, Translator). Jakarta, KencanaPrenada Media Grup.

17. Vel, Jacqueline A.C. 2008. "Uma Politics: An Ethnography of Democratization in West Sumba, Indonesia, 1986-2006". Leiden: KITLV Press.

18. Yasin, Muhammad, dkk. 2015. "Anotasi UU Nomor 6 Tahun 2014 tentangDesa”. Jakarta: PATTIRO.

19. Yin, Robert K. 2009. StudiKasus: DesaindanMetode. (M. DjauziMudzakir, Translator). Jakarta: Rajawali Press. 